\title{
Teaching NeuroImages: Distinguishing Papilledema From Pseudopapilledema Using Optical Coherence Tomography
}

Jasvir Virdee, BMedSc, MBChB, Ahoane Qureshi, BMedSci, MBChB, and Susan P. Mollan, MBChB, FRCOphth Neurology ${ }^{\circledR} 2021 ; 96:$ e2666-e2667. doi:10.1212/WNL.0000000000011353

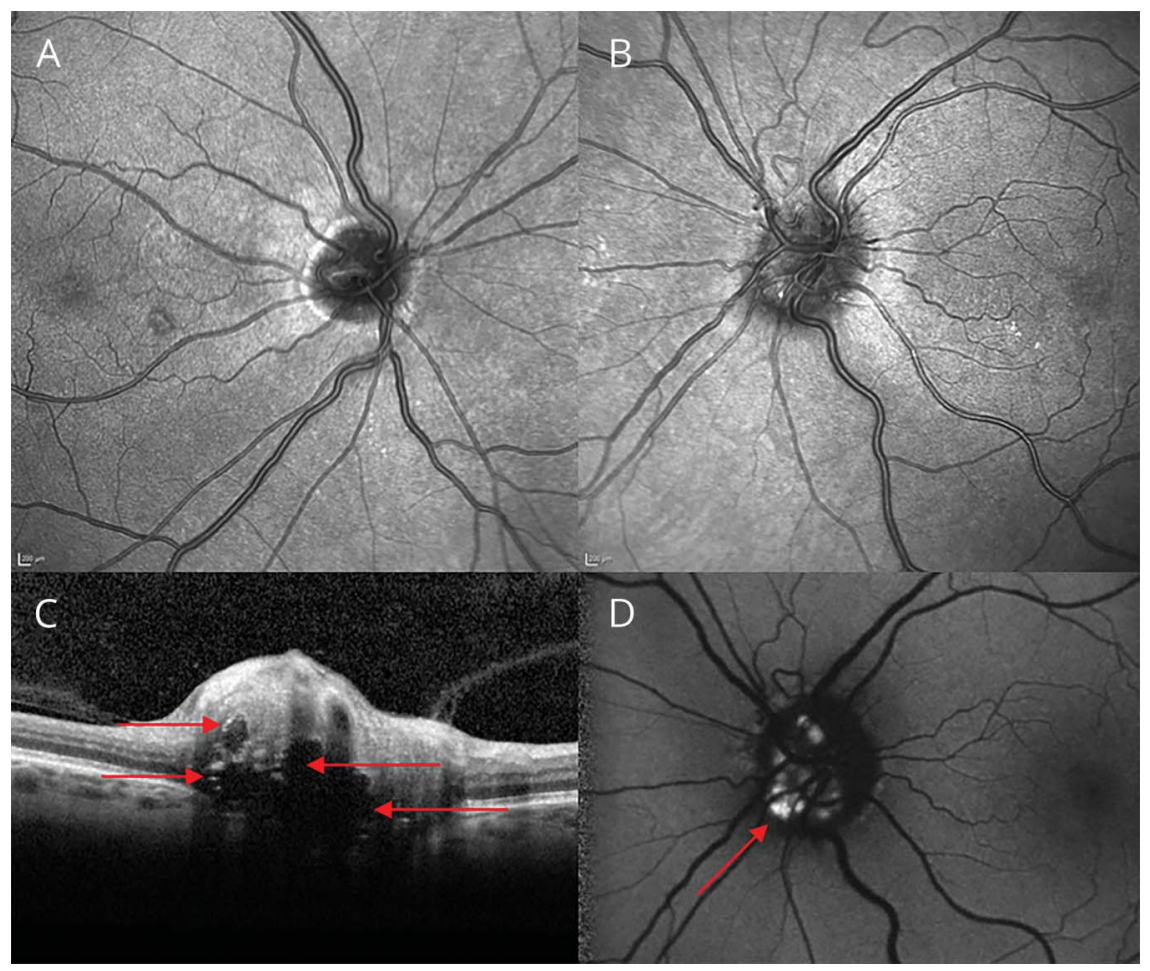

Normal optic nerve head and optic nerve head showing multiple hyperreflective lesions. (A) Infrared image of the right optic nerve head. (B) Infrared image of left optic nerve head shows an irregular elevated shape with high reflectivity in the inferior nasal portion of the disc. (C) Cross-section optical coherence tomography volume scan of left disc shows multiple hyperreflective changes around hyporeflective drusen (arrows). (D) Optical coherence tomography blue autofluorescence en face image of the optic nerve head shows multiple autofluorescent lesions throughout the inferior, nasal, and superior portions of the nerve.

A 71-year-old man presented to the emergency department with bilateral blurred optic discs, referred by his optometrist following a routine eye test. He had no visual or headache symptoms. Visual acuity was 20/20 bilaterally; funduscopy concurred with the optometry findings. Investigations for presumed papilledema were initially interpreted as normal (CT head/lumbar puncture). In clinic, optical coherence tomography (OCT) imaging identified optic disc drusen (ODD) (figure 1).

The invasive investigations could have been avoided if an ophthalmology examination had been performed to exclude pseudopapilledema, as recommended. ${ }^{1}$ ODD are common in the general

\section{Correspondence}

Dr. Mollan

susan.mollan@uhb.nhs.uk 
Figure 2 Neuroimaging

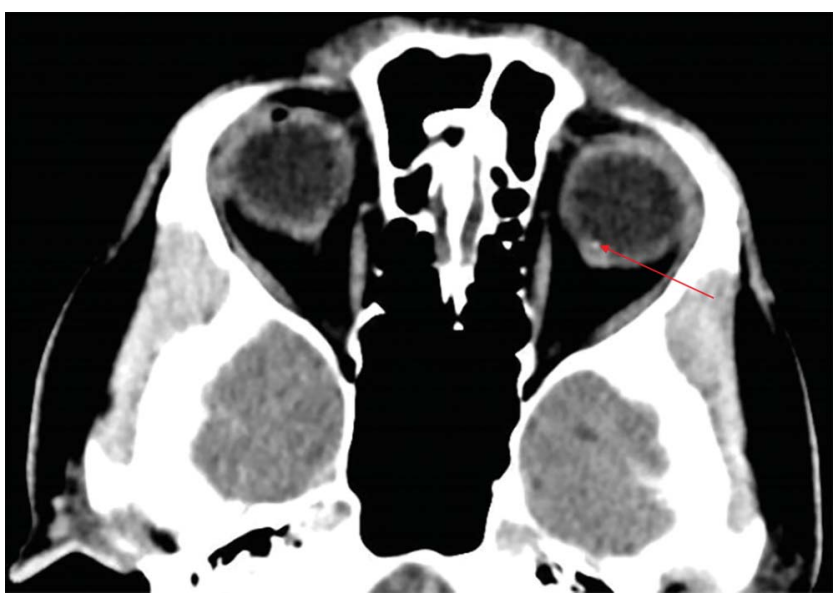

Axial CT head slice shows a calcified drusen (bright white spot; arrow) at the left optic nerve head.

population (up to $2.4 \%)^{2}$ They are clearly visualized with OCT imaging including cross-sectional optic nerve head volume scans and blue autofluorescence (figure 1D). Indeed, the CT head documented the drusen (figure 2). Although rarely ODD can coexist with papilledema, this is evident on both cross-sectional OCT imaging and dilated slit-lamp biomicroscope examination.

\section{Study Funding}

No targeted funding reported.

\section{Disclosure}

J. Virdee and A. Qureshi report no disclosures. S.P. Mollan receives royalties for Neuro-Ophthalmology: Global Trends in
Diagnosis, Treatment and Management and received funding for travel or speaker honoraria from the following commercial entities that are unrelated to the submission: Allergan: speaker bureau (2018); Roche: speaker and advisory board compensation (2016-2020); Chugai Pharma UK Limited: speaker and advisory board compensation (2017-2019); Heidelberg Engineering: speaker bureau (2019); Invex Therapeutics: advisory board (2020); Neurodiem: consultant (2019, 2020); Novartis: speaker bureau (2019); Santhera: speaker bureau and travel grant (2019); Santen: speaker bureau (2018). Go to Neurology.org/ $\mathrm{N}$ for full disclosures.

Appendix Authors

\begin{tabular}{|c|c|c|}
\hline Name & Location & Contribution \\
\hline $\begin{array}{l}\text { Jasvir Virdee, } \\
\text { BMedSc (Hons), } \\
\text { MBChB }\end{array}$ & $\begin{array}{l}\text { Birmingham Neuro- } \\
\text { Ophthalmology, Queen } \\
\text { Elizabeth Hospital, } \\
\text { Birmingham, UK }\end{array}$ & $\begin{array}{l}\text { Data collection, revised the } \\
\text { manuscript for intellectual } \\
\text { content }\end{array}$ \\
\hline $\begin{array}{l}\text { Ahoane } \\
\text { Qureshi, } \\
\text { MBChB, } \\
\text { BMedSci (Hons) }\end{array}$ & $\begin{array}{l}\text { Birmingham Neuro- } \\
\text { Ophthalmology, Queen } \\
\text { Elizabeth Hospital, } \\
\text { Birmingham, UK }\end{array}$ & $\begin{array}{l}\text { Data collection, drafted the } \\
\text { manuscript for intellectual } \\
\text { content }\end{array}$ \\
\hline $\begin{array}{l}\text { Susan P. } \\
\text { Mollan, } \\
\text { FRCOphth }\end{array}$ & $\begin{array}{l}\text { Birmingham Neuro- } \\
\text { Ophthalmology, Queen } \\
\text { Elizabeth Hospital, } \\
\text { Birmingham, UK }\end{array}$ & $\begin{array}{l}\text { Design and conceptualized } \\
\text { study, study supervision, } \\
\text { clinical care for the patient, } \\
\text { critical comments during } \\
\text { manuscript revision }\end{array}$ \\
\hline
\end{tabular}

\section{References}

1. Mollan SP, Davies B, Silver NC, et al. Idiopathic intracranial hypertension: consensus guidelines on management. J Neurol Neurosurg Psychiatry 2018;89: 1088-1100.

2. Malmqvist L, Bursztyn L, Costello F, et al. The optic disc drusen studies consortium recommendations for diagnosis of optic disc drusen using optical coherence tomography. J Neuroophthalmol 2018;38:299-307. 


\section{Neurology}

\section{Teaching NeuroImages: Distinguishing Papilledema From Pseudopapilledema Using Optical Coherence Tomography}

Jasvir Virdee, Ahoane Qureshi and Susan P. Mollan

Neurology 2021;96;e2666-e2667 Published Online before print December 8, 2020

DOI 10.1212/WNL.0000000000011353

This information is current as of December 8, 2020

\section{Updated Information \&} Services

References

Subspecialty Collections

Permissions \& Licensing

Reprints including high resolution figures, can be found at: http://n.neurology.org/content/96/21/e2666.full

This article cites 2 articles, 1 of which you can access for free at: http://n.neurology.org/content/96/21/e2666.full\#ref-list-1

This article, along with others on similar topics, appears in the following collection(s):

Optic nerve

http://n.neurology.org/cgi/collection/optic_nerve

Information about reproducing this article in parts (figures,tables) or in its entirety can be found online at:

http://www.neurology.org/about/about_the_journal\#permissions

Information about ordering reprints can be found online:

http://n.neurology.org/subscribers/advertise

Neurology ${ }^{\circledR}$ is the official journal of the American Academy of Neurology. Published continuously since 1951, it is now a weekly with 48 issues per year. Copyright () 2020 American Academy of Neurology. All rights reserved. Print ISSN: 0028-3878. Online ISSN: 1526-632X.

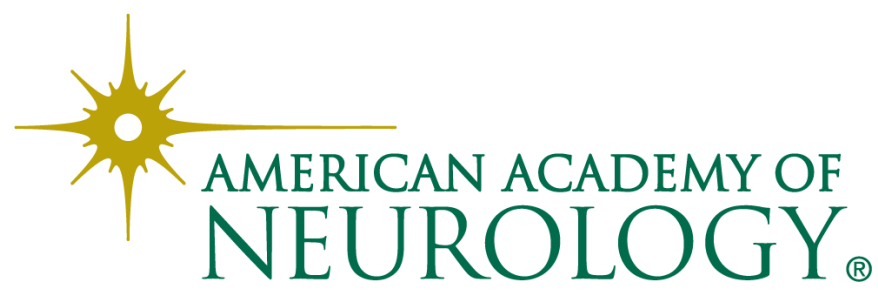

